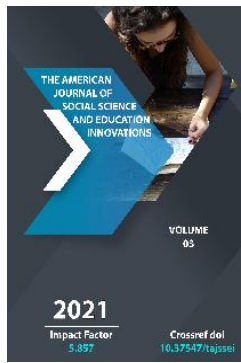

\title{
Russian Historians' Review Of Diplomatic Relations Between The Emirates Of Bukhara And The Russian Empire In Colonial Studies
}

\author{
Sunnatillo Hamraev \\ Master's Degree Of National University Of Uzbekistan
}

Journal Website:

http://theamericanjour

nals.com/index.php/taj

ssei

Copyright: Original content from this work may be used under the terms of the creative commons attributes 4.0 licence.

\section{ABSTRACT}

The first research on the history of diplomatic relations between the Emirate of Bukhara and the Russian Empire began in the XIX century. It is expedient to study how the diplomatic relations between the two countries were studied by Russian historians in the XIX and early XX centuries through historical research. This article discusses the general features of research in this period and the issues that are in their focus.

\section{KEYWORDS}

Diplomatic Relations, Yakovlev, Ernazarbiy, Trade Relations, S.V. Zhukovskiy, F.I. Lobysevich, fort, V.V. Bartold.

\section{INTRODUCTION}

The study of the history of diplomatic the Russian Empire began in the XIX century relations between the Emirate of Bukhara and 
historians and orientalists of the Russian Empire. Although the first works of this period do not fully meet the scientific requirements, it is expedient to accept them as research, as they were written by persons not directly involved in diplomatic relations and were published in scientific journals of their time. Among such researches was Yakovlev's collection "Mulla Irnazar Maksyutov, the Messenger of Bukhara" [1] and P. Yakovlev's such publications as "Russian Corporal Tupchiboshi u bukharskogo khana" [2] in the collection "Siberian Herald" of 1824 can be included. During this period a number of works were carried out by orientalists, in particular, it is expedient to study the researches of orientalists A. Semyonov [3], V.V. Grigoriev [4] military orientalist and historian A. Shepelev [5], F.I. Lobysevich [6], M.A. Terentev [7], S.V. Zhukovsky [8]. He has also published a number of scientific and scholarly popular articles. In particular, Yakovlev [9], Budrin [10], N.G. Zalesov [11], P.P. Shubinskiy [12], N. Researchers such as Ostroumov [13] have conducted research on a particular embassy.

Orientalists A. Semyonov and V.V. Grigoriev addressed this issue in general in the study of economic and political relations. The impact of diplomatic relations on trade and economic issues between the two countries was discussed.

In the analysis of the details of diplomatic relations in this period and the approaches to the facts related to it, it is expedient to pay attention to three main aspects:

- A study of the extent and importance of mutual embassy exchanges between the Emirate of Bukhara and the Russian Empire.

- Clarification of the reasons and tasks of diplomatic relations

- Goals and approaches to diplomatic relations

The study of diplomatic relations between the two countries during this period does not cover all the activities of the embassies between Bukhara and Russia and does not contain analytical research. However, there have been attempts on this issue. In particular, N. Ostroumov's article published in the Turkestan collection entitled "Bukhara and Khiva Embassy in Russia and the Russian Embassy in Bukhara and Khiva (Historical Parallel)" and S.V. Zhukovsky's study entitled " Russia's relations with Bukhara and Khiva over the last three hundred years " [14] can be cited.

N. Ostroumov's article on this subject also contains some confusing facts and comments. The author briefly dwells on embassies in his article, but the details and information given about some embassies are far from the truth. Also, the exchange of embassies was not consistent and the facts about the results of the embassies were not focused on the study of historical processes. Therefore, it should be noted that the scientific significance of this article is not high.

S.V. Zhukovsky's work covers a little more embassies. The causes and consequences of the many embassies exchanged in the relationship are summarized. However, due to the lack of scientific analysis and the fact that the purpose of embassy relations is described in a very short way, this research can be 
considered as a "brief reference". About this work V.V. Barthold's views are noteworthy. In particular, V.V. Barthold noted that "the study did not use archives and other open documents and did not refer to other sources, but was compilation in nature. Nevertheless, the work is considered to have a special place for the less rich Russian studies of Central Asia [15]. About this research another scientist who lived and worked in the Russian Empire and the Soviet era, A.A. Semenov notes that "nowhere in the work is there a clear reference from any archival document [16]". These considerations indicate that this study has never been considered a valuable study on the subject under study.

F.I. Lobysevich In his study of trade and diplomatic relations between Central Asia and Russia discusses relatively in detail the relationship between the Russian Empire and the Emirate of Bukhara. At the same time, he put forward some very interesting ideas. "The Russian government wanted to improve trade with Bukhara," he said. This was done not only as a Russian consumer of industrial products (as), but also to find a more reliable route between Orenburg and Bukhara to trade with the small khanates in the Amudarya basin, Afghanistan and North-West India "[17]. Apparently, with this approach, the author acknowledges that Russia seeks and is interested in diplomatic relations with Bukhara.

F.I. Lobysevich continued, "For this purpose, in 1802, a high-level decree was issued to send an ambassador to Bukhara under the leadership of Lieutenant Gaverdovsky. The embassy was sent in mid-1803, but failed to reach the borders of Bukhara "[18]. From this information, it can be concluded that the
Russian Empire had made practical efforts to establish relations with the Emirate of Bukhara.

F.I. Lobysevich also provides a number of noteworthy details about Russia's strategic plans. In particular, in 1819, the new commander of the Caucasus, the famous Erlomov, restored relations with the TransCaspian Turkmens. The aim was to pass through their lands to Khiva and Bukhara, from where they traded with North India[19]. In addition, Erlomov believed that a fortress should be built in the Gulf of Balkhan, not only to ensure trade, but also in case of war with Iran, as well as to serve as a base for the conquest of Bukhara and Khiva. In addition, if Bukhara and Khiva were occupied, Russia would have the opportunity to trade directly with North India (General Erlomov, ViceChancellor, April 21, 1820) [20]. These data prove once again that Russia intends to invade Central Asia in the future. Also, based on this information of the author, it can be concluded that the Russian Empire is eager to enter into diplomatic relations with Bukhara and other Central Asian countries.

On the development of diplomatic relations between the Emirate of Bukhara and the Russian Empire, F.I. Lobysevich also mentioned a number of diplomatic missions. In particular, at the request of the ruler of Bukhara Amir Haydar, in 1820 the state adviser to Bukhara A.F. Negri mission was to include three officers of the General Staff, including Baron Meyndorf, who had written a travelogue. The embassy arrived in Orenburg on October 10, under the protection of infantry and Cossacks, and the two armed detachments, accompanied by a total of 530 men, arrived in Bukhara in the second half of 
December 1820. They explored the entire route by defending the Khiva and Kazakhs during the voyage, as well as astronomically determining the width of several points [21]. However, the researcher, The results of A.F. Negri's mission are as follows: "This act ended with our diplomatic rapprochement with the Central Asian khanates of the time of Alexander I. We won at least something less than they did, "he said. The reason for this is that in relations with Khiva A. Bekovich (march - S.H. here F.I. Lobysevich wants to interpret this march as a diplomatic mission) suspected that the situation with Bukhara would also happen. However, it is noted that Bukhara is looking for ways to trade with Russia. For the next 20 years, trade with Khiva and Bukhara was carried out by trade caravans[22].

From these words it can be concluded that the aspiration of the Russian Empire to mutual diplomatic relations was more than the aspiration of the Emirate of Bukhara on trade and economic issues. It should be noted that in subsequent studies, It is shown that one of the important results of the A.F. Negri's embassy for the Russian Empire was the collection, analysis and drawing of various information about the country by its members [23]. One of the members of the diplomatic mission, Similar conclusions are made in E.K. Meyendorf's "Journey from Orenburg to Bukhara". Reflecting on the prospects of Bukhara-Russia trade relations, the author made the following long-term conclusions to solve the problems on this road: "If piracy and roadblocks on the road from Bukhara to Russia are eliminated, trade will expand significantly. If the Khiva khanate falls under Russian rule, the road will be absolutely safe[24]. So, The results of the A.F. Negri's mission were underestimated in the study of the period of the Russian Empire, focusing on its significance at that time. It can be seen that the materials collected by its members were not viewed as the results of a diplomatic mission.

The researcher, he spoke about the first trade caravan sent to Bukhara by the A.F. Negri mission under the agreement with Amir Haydar. In particular, “... the first caravan sent under the protection of the military failed. In the winter of 1824, two armed units, led by Colonel Tsiolkovsky, and a large caravan of 625 men, who had arrived in Orenburg, were attacked by Khiva and Kyrgyz in the Kyzylkum sands and forced to retreat, leaving most of their cattle behind. Moreover in 1822, the agreements on the return of captives and slaves were not fulfilled. In particular, the khan of Khiva, Allahqulikhan, did not give the captives, and the Emir of Bukhara also stated that he would not return the slaves in his territory[25]." At the same time, it proves that the Russian Empire tried to put the mutual agreement into practice. It also shows that the proposals put forward by the Emirate of Bukhara on the need to ensure the safety of trade caravan routes are not in vain.

Also, the arrival of F.I. Lobysevich Jan Vitkevich in Bukhara on the competition with the British on Central Asia, the sending of Butenev at the request of the Emir of Bukhara through his ambassador Boltaqulibek to send mining engineers to Bukhara, N. Ignatev gives a number of details about the mission. In general, F.I. Lobysevich approached BukharaRussia diplomatic relations from the point of view of Russia's interests, which is reflected in the comments on the achievements of these embassies. 
This study does not cover the activities of all embassies in the field of diplomatic relations between the two countries. However, the activities of the diplomatic missions of the Russian Empire have given reasonable feedback on their importance. They are approached mainly in terms of Russia's role in the conquest of Central Asia and in competition with the British.

M.A. Terentev's History of the Conquest of Central Asia briefly discusses the diplomatic relations between the Emirate of Bukhara and the Russian Empire. In his approaches to relationships, this is in line with F.I. Lobysevich's views.

The peculiarity of F.I. Lobysevich and M.A.Terentev's work is that these works are approached from the point of view of studying the history of the Russian Empire's conquest of Central Asia. Perhaps that is why the government's intentions in sending ambassadors from Russia to Central Asia were not covered, and the embassies sent from Central Asia were not studied. This situation prevents this work from being included in the list of excellent works in the study of diplomatic relations between the Emirate of Bukhara and the Russian Empire. At the same time, it should be noted that research shows that Russia has long planned to invade the Central Asian states, and this is exactly the goal of diplomatic relations.

In this regard, it is worth noting that the views on the activities of the embassy of Ernazar Maqsud oglu, which is the first of the diplomatic relations between the two countries, differ from the above. Studies of the Russian Empire have shown that the reason for sending an ambassador from
Bukhara to Russia after a long break was primarily the initiative of the Emirate of Bukhara to restore or establish relations between the two countries, mainly in the interests of Bukhara. In particular, the first study of the embassy, published by Yakovlev in 1824 in the collection "Siberian Herald" under the title "Mulla Irnazar Maksyutov, the messenger of Bukhara", Asking the Russian government to compensate for the damage of Bukhara caravan caused by kyrgyzes and Pugachev looting, he said that he had been sent from Bukhara to Russia as an ambassador in order to secure the trade route that was convenient for the people of Bukhara [27].

In particular, the following approach is taken to ensure the security of trade routes - the safe passage of Orenburg and the Russian state in general through the Kyrgyz desert, not through Mangistau and rejected it because it aroused relatively unfounded suspicions among the people of Bukhara and it would be always in the danger of kyrgyzes[28].

At this point, when comparing the construction of the fort with the research of the next period, there is a discrepancy in the data. In particular, researcher Kh. Gulomov in his monograph quoted archival sources as saying, "According to the ambassador, it is expedient to build a Russian fort on the banks of the Emba River, where trade caravans can find shelter if necessary"[29].

The reason for the second embassy was to recoup the damage caused by the looting of Bukhara merchants and to allow the Bukhara people to pass through Russia to Constantinople (Istanbul - S.H.) and from there to Mecca [30]. 
Research on the period of the Russian Empire covers the reasons for sending the embassy of Ernazar Maqsud oglu mainly on the basis of the interests of the Emirate of Bukhara. In establishing diplomatic relations, the main focus is on the robbery of traders, the reasons for ensuring the security of trade routes. The interests of the Russian side in the establishment of diplomatic relations, as well as the resolution of various political issues by the embassy in subsequent political processes, which may be beneficial for both countries, have not been taken into account. He also proudly noted that the embassy had achieved its goals, ie that the traders had not been compensated for the looting, but that the ambassador had returned with large gifts, like with the present of Ecaterina II they built madrasah[31].

We can see a short and one-sided approach Ernazar Maqsud oglu embassies in Yakovlev, S.V. Zhukovsky's research. However, P.P. Shubinsky made some noteworthy remarks about the importance of the embassy for both sides and its role in future political and strategic goals. In particular, during the first embassy, Ernazarbi met with the ambassador of the Usmonli Turks in Moscow several times. During these meetings, they discussed the establishment of trade relations between the Emirate of Bukhara and the Usmonli Turks, as well as the movement of Central Asian pilgrims through Khiva and Astrakhan to Mecca, the southern Russian borders and the Black Sea to Constantinople and Anatolia[32]. Researcher P.P. Shubinsky puts forward a number of comments on the impact of this conversation on diplomatic relations between the Usmonli Turkic state and Bukhara. In particular, it is noted that the Turkish sultan sent an envoy to the khan of Bukhara, and in response the embassy was sent in 1779 under the leadership of Ernazarbiy and his son [33]. The ambassador also states that he first came to Russia to recover damages from the robbery of an unpaid trade caravan, even after his initial request at the embassy, and to request the 3,000,000 poods [34] of copper needed by the Bukhara government[35].

P.P. Shubinsky mentions that the ambassador Ernazar had the idea of returning trade relations between East Asia and Western Europe to their previous routes from the Caspian coast through the Black Sea and the Baltic Sea. He also argues that this idea did not materialize due to Ernazarbi's death and his focus on other pressing issues in Russia's foreign policy [36].

Based on the above data, we can see that the relations between the two countries have gained not only trade and economic issues, but also political significance.

In conclusion, the study of diplomatic relations between the Russian Empire and the Emirate of Bukhara shows that the period of the empire had its own views, in particular, the initial period of relations and the initiative in the first embassy was assessed by the Emirate of Bukhara. Diplomatic relations since the beginning of the 19th century show that the aspirations of the Russian Empire have intensified. Articles from this period are devoted to the details of certain embassies. In particular, within the framework of diplomatic relations between the Emirate of Bukhara and the Russian Empire, Ernazarbiy, A.F. Negri, K. Butenev, N. Embassies like Ignatev are more studied. 
Research conducted during the Russian Empire cites the reasons for the establishment of diplomatic relations as the two countries' interest in cooperation and the development of trade relations, the release of Russian prisoners of war in the Russian Empire. At the same time, the research tends to portray the Russian Empire as a dominant party in the relationship. The colonial interests of the Russian Empire in relation to Central Asia, as well as the competition with Britain for the region, are also highlighted in a way that is in line with historical reality.

\section{REFERENCES}

1. Яковлев. Мулла Ирназар Максютов, посланник бухарский // Сибирский вестник. Ч. І. 1824.

2. Яковлев П. Русский капрал Тупчибоши у бухарского хана // Отечественные записки,1822, част II кн. XIX.;

3. Семенов А. Изучения исторических сведений о Российской внешней торговле и промышленности с половины XVII столетия по 1858 г., Спб., 1859.

4. Григорьев В.В. Русская в отношении Средней Азии. СПб., 1874; Григорьев В.В. Международный съезд ориенталистов 3-й. Спб, 1879-1880; Григорьев В.В. Разбор соченения П.И.Небольсина Очерки торговли России с Средней Азией.; Григорьев В.В. Оботношениях между кочевными народами и оседлыми государствами Спб., 1875.

5. Шепелев А. Материалы для история Хивинскаго похода 1873 года. Очерк военных и дипломатических сношений России с Среднею Азиею.Ташкент., 1879.
6. Лобысевич Ф.И. Поступательное движение в Среднюю Азию в торговом и дипломатическо-военном отношении. СПб., 1900.

7. Терентьев М.А. История зоваевание Средней Азии съ картами и планами. СПб. 1906.

8. Жуковский С.В. Сношения России с Бухарой и Хивой за последнее трехсотлетие. Пг, 1915.

9. Яковлев. Мулла ИрназарМаксютов, посланник бухарский // Сибирский вестник. Ч. І. 1824.

10. Будрин. Русские в Бухаре в 1820 году (Записка очевидца) // Туркестанский сборник. Т. 239. - СПб., 1880. С. 32.

11. Залесов Н.Г. Письмо из Бухари. // Военный сборник, 1860 №4

12. Шубинский П.П. Бухарские посольства при дворе Екатерины II // Исторический вестник, № 2.1897. С. 519-538.

13. Остроумов Н. Бухарския и Хивинския посольства въ Россию и русския посольства въ Бухару и Хиву (Историческа параллель) // Туркестанский сборник Т. 436. 1907.

14. Жуковский С.В. Сношения России с Бухарой и Хивой за последнее трехсотлетие. Пг, 1915.

15. Бартольд В.В. Рецензия на книгу С.В. Жуковского “Сношения России С Бухарой и Хивой за последнее трехсотлетие". Труды Общества русских Ориенталистов. № 2. ХІІ Петроград. 1915. Сочинения ч 2. Москва. 1964. 419-422-бетлар.

16. Семенов А.А. $\mathrm{K}$ истории дипломатических сношений между Россией и Бухарой в начале XIX в. // известия АН УзССР. Ташкент, 1951, № 1. 85-бет. 
17. Лобысевич Ф.И. Поступательное движение в Среднюю Азию в торговом и дипломатическо-военном отношении. СПб., 1900. 63-Ст.

18. In that place

19. That work. P 65 .

20. Лобысевич Ф.И. Поступательное движение в Среднюю Азию в торговом и дипломатическо-военном отношении. СПб., 1900. 67-бет.

21. That work. $P 68$.

22. That work. P 69.

23. Historical essays and excerpts from the history of Uzbek diplomacy. Xayrullaev M.M. under editing. Tashkent., 2003. 215 pages.

24. In that place.

25. Лобысевич Ф.И. Поступательное движение в Среднюю Азию в торговом и дипломатическо-военном отношении. СПб., 1900. 70-Ст

26. Терентьев М.А. История завоевания Средней Азии с картами и планами. Том І. СПб., 1906.

27. Яковлев. Мулла Ирназар Максютов, посланник бухарский // Сибирский вестник. Ч.І. 1824. 7-ст.

28. That work. $\mathrm{P} 8$.

29. ГуломовX. Дипломатические отношения государств средней Азии с Россией в XVIII - первой половине ХІХвека.Ташкент: Фан. 2005. 172- ст.

30. Яковлев. Мулла Ирназар Максютов, посланник бухарский // Сибирский вестник. Ч.І. 1824. 10- ст.

31. ШубинскийП.П. Бухарские посольства при дворе Екатерины II // Исторический вестник, № 2. 1897. 519-520-бетлар., Жуковский С.В. Сношения России с Бухарой и Хивой за последнее трехсотлетие. Пг, 1915. 89-ст.
32. Шубинский П.П. Бухарские посольства при дворе Екатерины II // Исторический вестник. № 2.1897. 528- ст.

33. In that place.

34. Pood is an obsolete unit of weight included in the Russian system of units of measurement. 1 pound was equivalent to 16.380496 pounds.

35. Шубинский П.П. Бухарские посольства при дворе Екатерины II // Исторический вестник. № 2. 1897. 529-ст.

36. Look deeply: Following work. 537-page.

37. Саидбобоев, 3. А., Рахмонкулова, 3. Б., \& Адилов, Ж. Х. (2016). Подготовка кадров архивистов в Узбекистане. Документ. Архив. История. Современность.-Екатеринбург, 2016, 514-518.

38. Адилов, Ж. Х. (2014). Архивные документы о завоевании Туркестанского края (на примере похода ВА Перовского). Документ. Архив. История. Современность.Екатеринбург, 2014, 160-162.

39. Nazarov, A. Y. (2020). Analysis of historical and geographical research conducted in the governor-general of Turkestan. ACADEMICIA: An International Multidisciplinary Research Journal, 10(11), 858-863.

40. Назаров, А. (2021). ТУРКИСТОН ҚИШЛОҚ ХЎЖАЛИГИ ЖАМИЯТИ ФАОЛИЯТИ ТАРИХИДАН (ЎЗМА И-103 фонди асосида). ВЗГЛЯД В ПРОШЛОЕ, 4(2). 